\title{
Рецензія на монографію "Некротизирующий фасциит" / М. В. Гринев, Кир. М. Гринев. - СПб. : Гиппократ, 2008. - 120 с.
}

\author{
CRITIQUE FOR THE MONOGRAPH “NECROTIZING FASCIITIS" / M.V. HRYNEV, KYR. M. HRYNEV. -SPb. : \\ HIPPOKRAT, 2008. - 120 p.
}

Рецензована монографія чи не єдина слов'яномовна праця такого об'єму на згадану тему. Про актуальність ï̈ свідчать статистичні дані щодо смертності при цій нозології, котра сягає 100 \%, а при лікуванні - 75 \%. Більше того, поширеність гнійно-запальних процесів м'яких тканин у хірургічному стаціонарі становить близько третини контингенту хворих. Дві проблеми переплелися у цій важкій хірургічній патології-поширені некрози поверхневої фасції і підшкірної клітковини та ендотоксикоз із поліорганною недостатністю. Обмаль клінічних спостережень, поодинокі випадки в переважній більшості створюють фон, де зібрані автором 50 випадків некротичного фасціїту роблять монографію вагомою.

Безперечно, некротичний фасціїт належить до екстремальних хірургічних захворювань, а тому дані монографії мають, певною мірою, пізнавально-методичний характер вивчення критичних станів в організмі людини. Останні, на думку Г. Сельє, незалежно від своєї природи мають єдиний унітарний механізм свого розвитку.

У першому розділі рецензованої монографії автори подають анатомічні дані щодо поверхневої фасції тіла людини. Сам термін “некротизуючий (чи некротичний) фасціїт", на думку авторів, був запропонований в 1952 році B. Wilson. Проте в літературі описані випадки ефективного лікування фасціїту промежинної локалізації, що називається гангреною Фурньє. Це стосується 18-19 ст. і наведено в публікаціях Baurienne, И. В. Буяльского і П. Добычина. Далі наводяться фактори ризику розвитку фасціїту, серед яких вживання ін'єкційних наркотиків, цукровий діабет, онкопатологія і хронічні процеси в організмі. Ці дані узгоджуються з власними даними.

У другому розділі розглядається мікробний фактор, що спричиняється до цього захворювання. Тут виділяють Str. pyogenes, аеробно-анаеробні мікробіоти та кишкову флору, зокрема неклостридіальні анаероби, яким надають вагому роль в розвитку хвороби. У 18-20 \% випадків при ідіопатичному епіфасціїті виділити флору не вдалося. Наш власний досвід лікування хворих на гангрену Фурньє, як вид фасціїту з локалізацією на промежені, засвідчує участь у цьому процесі неклостридіальних анаеробів. Це доводить зловонний запах ексудату, виділення газу при розкритті пошкоджених тканин та превалювання некротичних змін у тканинах над запальними.

У третьому розділі подано роздуми авторів стосовно патогенезу цього захворювання. Тут вперше наведено оригінальне трактування механізмів розвитку процесу, зумовлених анатомічними особливостями поверхневої фасції тіла. Так, особливістю ангіоархітектоніки останньої $€$ наявність поверхневого та глибокого пластів фасції, які пронизані судинами, що утворюють сітку за типом шнурованої драбини. Фасція має від 3-4 до 30 шарів колагенових та еластичних волокон, які різко обмежують в об'ємі і роблять резистентним паравазальний простір. При дії патогенного фактора виникає гіперкоагуляція з інгібованим фібринолізом, виражений паравазальний вихід рідкої частини крові, котрий через розвинуту сітку волокон посилює ішемію тканин фасції і посилює розлади мікроциркуляції та активує цитокіновий каскад. Відтак, розлади мікроциркуляції ведуть до тромбозу судин, некрозу поверхневої фасції, а тому до системної запальної реакції організму з ендотоксикозом і поліорганною недостатністю.

У четвертому розділі подано патологоанатомічні дані, отримані у хворих на некротичний фасціїт. Так, для цього процесу характерні поширені зони некрозу 2-3 рівня за шкалою D. Ahrenholz, 1988 та переважання в біоптаті некротичних змін над запальними. Ось чому автори вперше з власного досвіду наполягають при підозрі на некротизуючий фасціїт виконувати в обов'язковому порядку доопераційну діагностичну кріобіопсію матеріалу з уражених зон.

У п’ятому розділі розкрито клінічну картину захворювання, де на початку процесу виділяють два основні прояви. Перш за все, біль у всьому тілі, зумовлений здавленням нервових закінчень у поверхневій фасції тіла через набряк у зв'язку із порушенням мікроциркуляції і випотіванням рідини в паравазальний простір, який резистентний і обмежений в об'ємі через розвинену сітку волокон. Другий прояв - лихоманка (пропасниця), що є виявом відповіді організму на інфекцію з розвитком інтоксикації. Далі приєднуються місцеві зміни - гіперемія шкіри з формуванням некрозів. Автори розріз- 
няють некротичний фасціїт першого типу, некротичний фасціїт другого типу - клінічна модель екстремального стану. За локалізацією розрізняють фасціїт тулуба, кінцівок, голови та шиї, промежини (гангрена Фурньє).

Наш власний досвід охоплює лікованих мною 12 хворих із гангреною Фурньє тяжкого перебігу та двох хворих, консультованих мною в інших відділах. Крім цього, два хворих із фасціїтом тулуба з локалізацією в ділянці грудної залози та передньої черевної стінки. Він засвідчує, що промежинний фасціїт - тяжкий анаеробний процес, що охоплює, крім поверхневої фасції, підшкірної клітковини і шкіри промежини, в 8 \% випадків тіло статевого члена, в $30 \%$ - паренхіму яєчок, в $10 \%$ - сечовий міхур і парауретральну клітковину, в 3 \% пряму кишку, тобто поширюється значно глибше, ніж поверхнева фасція тіла. Крім цього, процес супроводжується вираженим ендотоксикозом.

У шостому розділі подано діагностику епіфасціїту. Особливих, патогномонічних, ознак цього захворювання не існує. Щодо діагностичних обстежень, то рекомендують виконувати оглядову рентгенографію, магнітно-резонансну томографію та комп'ютерну томографію в ураженій зоні на предмет пошуку в тканинах наявного газу. Наш власний досвід підтверджує це.

У сьомому розділі автори наводять лікувальну тактику, яку вони застосовують у хворих на епіфасціїт. Золотим стандартом є лампасні розтини шкіри, підшкірної клітковини та поверхневої фасції тіла в зоні ураження, що виконується в ургентному порядку через 3-6 год з моменту госпіталізації після інтенсивної внутрішньовенної терапії з подальшою оперативною ревізією рани і некректоміями не пізніше 12-24 год від першого оперативного втручання та подальшими етапними некректоміями. При лікуванні своїх хворих ми користувались ідентичною тактикою.

Крім оперативного втручання, автори застосовували ступінчасту антибактеріальну терапію 3 частою зміною антибіотиків, імуномодулюючу терапію (протигангренозна сироватка, плазма крові, імуноглобуліни, ронколейкін), імуносупресивну терапію (глюкокортикоїди), антицитокінову терапію (пентоксифілін), засоби для поліпшення метаболізму, гіпербаричну оксигенацію. Ми застосовували ідентичну тактику, окрім гіпербаричної оксигенації, з одної сторони, за відсутності у нас барокамери, а 3 іншої - враховуючи негативний вплив кисню оксидантний стрес.

Автори чи не вперше застосували препарат активованого протеїну С під торгівельною назвою “Зигрис", мотивуючи це наявністю у хворих на некротичний фасціїт системної запальної реакції в організмі, що вимагає протизапальної, антикоагулянтної і профібринолітичної терапії. Вказані якості притаманні препарату “Зигрис".

У 8 розділі подано тактику стосовно інтенсивної інфузійної терапії при фасціїті. Вона має фазовий характер. Так, в 1-2-гу добу лікування об'єм внутрішньовенної інфузії має складати 5-8,5 л, а на 2-5-ту добу - 3-5 л з подальшим зменшенням об'єму інфузії до 2 літрів на добу. Крім цього, в перші доби лікування 50-75 \% об'єму добової інфузії мають складати кристалоїди, а 3 3-го дня лікування понад половину інфузії на добу мають складати глюкозоелектролітні суміші. Ці дані узгоджуються 3 нашими власними даними і даними публікацій з цієї теми. Для профілактики стресового пошкодження шлунково-кишкового тракту показаний антацид сукралфат та антагоністи Н2 рецепторів.

У 9 розділі подано нутритивну підтримку хворих на фасціїт - ентеральне і парентеральне харчування. Воно узгоджується з нашими поглядами.

3 огляду на все вищезгадане, монографія $\epsilon$ цінною як для хірургів, урологів, анестезіологів-реаніматологів, так і для патофізіологів. Це перша ластівка у слов'яномовній медичній літературі щодо такого тяжкого гнійно-некротичного процесу, як фасціїт.

Лікар-уролог Трускавецької міської лікарні, кандидат медичних наук, доцент Олег Прийма

Отримано 20.01.13 